Jurnal Cahaya Keadilan

P-ISSN: 2339-1693

Vol. 9 No. 2 Oktober 2021

E-ISSN: 2580-2461

Program Studi Ilmu Hukum Universitas Putera Batam

\title{
IMPLEMENTASI PASAL 17 UNDANG-UNDANG NOMOR 5 TAHUN 1999 TERHADAP RULE OF REASON (STUDI DI KOMISI PENGAWASAN PERSAINGAN USAHA WILAYAH II KOTA BATAM)
}

\author{
Ukas $^{1}$, Zulkifli $^{2}$ \\ ${ }^{1}$ Fakultas Ilmu Sosial Dan Humaniora Universitas Putera Batam, E-mail: Ukas@puterabatam.ac.id \\ ${ }^{2}$ Sekolah Tinggi Ilmu Hukum, E-mail: zulfly03@gmail.com
}

\begin{abstract}
Abstrak
Undang-Undang Nomor 5 Tahun 1999 Tentang Larangan Praktek Monopoli dan Persaingan Usaha Tidak Sehat sebenarnya tidak lepas dari krisis moneter yang kemudian berlanjut kepada krisis ekonomi yang melanda Indonesia dipertengahan tahun 1997, dimana pemerintah didasarkan bahwa sebenarnya Fundamental ekomoni Indonesia terjadi karena beberapa kebijakan pemerintah di beberapa sektor ekonomi yang kurang tepat yang menyebabkan pasar menjadi terdistorsi (penjelasan UndangUndang Nomor 5 Tahun 1999 Tentang Larangan Praktek Monopoli dan Persaingan Usaha Tidak Sehat). Dunia persaingan usaha adalah dunia yang kompleks dan mencangkup beberapa sektor kehidupan termasuk sektor-sektor vital yang bersentuhan langsung dengan kehidupan masyarakat. Harmonisasi Pasal 17 Undang-Undang Nomor 5 Tahun 1999 Tentang Larangan Praktek Monopoli dan Persaingan Usaha Tidak Sehat yang tertuang didalam BAB IV Tentang Kegiatan yang dilarang pada bahagian Monopoli pelaku usaha dilarang melakukan penguasaan atas produksi dan/atau pemasaran barang dan/atau jasa yang dapat menyebabkan terjadinya praktek Monopoli atau persaingan usaha yang tidak sehat. Pelaku usaha patut di duga atau di anggap bersalah.

Tujuan dari pengajuan penelitian ini nantinya di harapkan untuk: Pertama, Memberikan Pemahaman Kepada Pelaku Usaha Hal-Hal atau Pendekatan Terhadap Pelanggaran Baik Bersifat Perjanjian yang di Larang Maupun Pelanggaran Bentuk Lainnya. Kedua, Memberikan Pemahaman Kepada Pihak (Pelaku Usaha) Tentang Mencegah Praktek Monopoli dan/atau Perjanjian Usaha yang Tidak Sehat Baik yang di Atur dalam Pasal 5 dan Pasal 17 Undang-Undang Nomor 5 Tahun 1999 Tentang Larangan Praktek Monopoli dan Persaingan Usaha Tidak Sehat, Termasuk Sanksi atas Pelanggaran dari Kedua Pasal Tersebut. Penelitian ini di lakukan dengan jenis Penelitian yuridis empiris yaitu penelitian yang langsung terjun ke lapangan.
\end{abstract}

Kata Kunci: Praktek Monopoli, Rule Of Reason 
Program Studi Ilmu Hukum Universitas Putera Batam

\section{PENDAHULUAN}

Lahirnya Undang-Undang Nomor 5 Tahun 1999 Tentang Larangan Praktek Monopoli dan Persaingan Usaha Tidak Sehat sebenarnya tidak lepas dari krisis moneter yang kemudian berlanjut kepada krisis ekonomi yang melanda Indonesia dipertengahan tahun 1997, dimana pemerintah didasarkan bahwa sebenarnya Fundamental ekomoni Indonesia terjadi karena beberapa kebijakan pemerintah di beberapa sektor ekonomi yang kurang tepat yang menyebabkan pasar menjadi terdistorsi (penjelasan Undang-Undang Nomor 5 Tahun 1999 Tentang Larangan Praktek Monopoli dan Persaingan Usaha Tidak Sehat).

Undang-Undang Nomor 5 Tahun 1999 Tentang Larangan Praktek Monopoli dan Persaingan Usaha Tidak Sehat yang disusun untuk menegakkan aturan hukum dan memberikan perlindungan yang sama bagi setiap pelaku usaha dalam upaya untuk menciptakan persaingan usaha yang sehat, serta memberikan jaminan kepastian hukum untuk lebih mendorong percepatan pembangunan ekonomi dalam upaya meningkatkan kesejahteraan umum (penjelasan Undang-Undang Bagian Umum Undang-Undang Nomor 5 Tahun 1999 Tentang Larangan Praktek Monopoli dan Persaingan Usaha Tidak Sehat). Tenyata dalam implementasinya dirasakan kurang berjalan dengan efektif, kurang efesiensi implementasi dari Undang-Undang Nomor 5 Tahun 1999 Tentang Larangan Praktek Monopoli dan Persaingan Usaha Tidak Sehat di karenakan Kelembagaan Komisi Pengawasan Persaingan Usaha yang kurang diatur secara 
mendalam didalam Undang-Undang Nomor 5 Tahun 1999 Tentang Larangan Praktek Monopoli dan Persaingan Usaha Tidak Sehat.

Harmonisasi Pasal 17 Undang-Undang Nomor 5 Tahun 1999 Tentang Larangan Praktek Monopoli dan Persaingan Usaha Tidak Sehat yang tertuang didalam BAB IV Tentang Kegiatan yang dilarang pada bahagian Monopoli pelaku usaha dilarang melakukan penguasaan atas produksi dan/atau pemasaran barang dan/atau jasa yang dapat menyebabkan terjadinya praktek Monopoli atau persaingan usaha yang tidak sehat. Pelaku usaha patut di duga atau di anggap bersalah.

Pendekatan terhadap pelanggaran Undang-Undang Nomor 5 Tahun 1999 Tentang Larangan Praktek Monopoli dan Persaingan Usaha Tidak Sehat. Pendekatan dalam hal meliputi Per Sel Illegal, yaitu setiap perjanjian atau kegiatan usaha tertentu di anggap tidak diperlukan pembuktian lebih lanjut atas dampak persaingan usaha yang tidak sehat yang dapat ditimbulkan dari perjanjian atau kegiatan tersebut.

Selaku Per Sel Illegal juga di dalam Pasal 17 tentang Monopoli. Dalam pasal 130 Undang-Undang Nomor 5 Tahun 1999 Tentang Larangan Praktek Monopoli dan Persaingan Usaha Tidak Sehat, sesuatu pendekatan guna mengevaluasi akibat dari perjanjian atau kegiatan usaha tertentu sehingga dapat ditentukan apakah perjanjian atau kegiatan usaha tersebut bersifat menghambat atau mendukung persaingan, contoh Pasal 17 tentang monopoli: Lebih lanjut kegiatan pendekatan terhadap pelanggaran Undang-Undang Nomor 5 Tahun 1999 Tentang Larangan Praktek Monopoli dan Persaingan Usaha Tidak Sehat meliputi perjanjian yang dilarang dapat ditemui dari 
Jurnal Cahaya Keadilan

P-ISSN: 2339-1693

Vol. 9 No. 2 Oktober 2021

E-ISSN: 2580-2461

Program Studi Ilmu Hukum Universitas Putera Batam

Pasal 4 sampai dengan Pasal 16 Undang-Undang Nomor 5 Tahun 1999 Tentang Larangan Praktek Monopoli dan Persaingan Usaha Tidak Sehat, sedangkan perbuatan atau kegiatan yang di larang dapat ditemui di Pasal 17 sampai dengan Pasal 24 UndangUndang Nomor 5 Tahun 1999 Tentang Larangan Praktek Monopoli dan Persaingan Usaha Tidak Sehat.

Dari latar belakang penelitian diatas maka pengusul tertarik untuk mengangkat judul Implementasi Pasal 17 Undang-Undang Nomor 5 tahun 1999 terhadap Rule Of Reason (Studi di Komisi Pengawasan Persaingan Usaha Wilayah II Kota Batam).

\section{METODE PENELITIAN}

Penelitian ini merupakan penelitian normatif (Normative Approach) yaitu Undang-undang disamping bertumpu pada penelitian normatif, juga ditambah dengan pendekatan teoritis. Selanjutnya dalam menganalisis data digunakan pendekatan kualitatif dan juga didasarkan studi berbasis perpustakaan, yang berarti bahwa bahan yang diperlukan untuk penelitian harus tersedia di perpustakaan, arsip, dan database, undang-undang dan dokumen lainnya (Ibrahim, 2005). 
Jurnal Cahaya Keadilan

P-ISSN: 2339-1693

Vol. 9 No. 2 Oktober 2021

E-ISSN: 2580-2461

Program Studi Ilmu Hukum Universitas Putera Batam

\section{PEMBAHASAN}

\subsection{Hasil Penelitian}

\subsubsection{Penegakan hukum persaingan usaha di kaitkan dengan Pasal 17 Undang- Undang Nomor 5 Tahun 1999}

Dalam kegiatan usaha dan bisnis di antara para pelaku Usaha kerap kali ditemukan persaingan usaha yang akibatnya tentu ada pihak (pihak konsumen atau pedagang lainnya menui kerugian) dan atau setidak-tidanya mempersempit pasar bagi pelaku usaha tersebut, dan itu jelas bertentanggan dengan Undang-Undang Nomor 5 Tahun 1999 secara umum dan Pasal 17 Undang-Undang Nomor 5 Tahun 1999 secara khusus. Untuk itu penagakan hukum sangat di rasa penting sesui amanat dari pemerintah Undang-Undang persaingan usaha. Undang-Undang persaingan usaha dengan cara kesepakatan baik yang diterangkan dalam perjanjian sesui Pasal 1338, 1320 dan PAsal 1365 KUHPerdataberjalan secara harmonis dan pleksible. Didalam Undang-Undang perjanjian usaha kebijakan pengusaha dengan kebijakan pemerintah yang terkait harus sejalan dan saling mendukung karena dalam kenyataan sehari-hari pelanggaran Pasal 17 Undang-Undang Nomor 5 Tahun 1999 masih saja didapati dan dirasakan dalam dunia bisnis, karena kerap menghambat kuantitas dan kualitas produksi dan pemesanan barang dan atau jasa untuk sampai di tengah-tengah konsumen (pemakai) baik pada konsumen awal maupun pada konsumen akhir berdasarkan Undang-Undang Nomor 8 TAhun 1999, dan untuk lebih jelasnya pelaku usaha harus menghindari antara lain sebagai berikut: 
1. Pelaku usaha di larang melakukan persaingan atas produksi dan atau persamaan barang dan atau jasa yang mengarah atau dianggap melakukan penguasaan atas produksi yang mengakibatkan praktek monopoli dan persaingan usaha tidak sehat.

2. Pelaku usaha patut diduga atau di anggap melakukan penguasaan atas produksi atau atas persamaan barang dan atau jasa yang dapat merusak atau mengakibatkan kerugian.

3. Arahan yang jelas dalam Pasal 17 Undang-Undang Nomor 5 Tahun 1999 Tentang Persaingan Usaha Tidak Sehat, merupakan landasan dalam beretika dan atau berprilaku agar tidak satu orangpun para pelaku usaha merasa dirugikan dan atau tidak diperhatikan oleh pemerintah dan pelaku usaha dimana posisi dominannya lebih atas.

4. Dalam menjelaskan pemahaman dan pengaturan Monopoli dari segi persaingan menjelaskan tentang dampak monopoli, menjelaskan nilai-nilai dan unsurunsur penguasaan dalam kaitannya Pasal 17 Undang-Undang Nomor 5 Tahun 1999.

Dengan adanya aturan (pengaturan) yang merupakan pedoman utama untuk menyikapi terlaksananya pasal 17 Undang-Undang Nomor 5 TAhun 1999, secara praktis, hukum dengan ekonomis. Pemerintah dan masyarakat umum diharapkan mampu memahami apa maksud dari suatu ketentuan atas metode pendekatan yang ada dalam Pasal 17 Undang-Undang Nomor 5 Tahun 1999, 
Jurnal Cahaya Keadilan

P-ISSN: 2339-1693

Vol. 9 No. 2 Oktober 2021

E-ISSN: 2580-2461

Program Studi Ilmu Hukum Universitas Putera Batam

dan bagi Komisi Pengawas Persaingan Usaha (KPPU) yang merupakan Lembaga Independen yang dibentuk untuk mengawasi pelaksanaan UndangUndang Nomor 5 Tahun 1999. Manfaat pedoman itu sekaligus merupakan salah satu program, KPPU dalam melaksanakan tugas-tugas terutama yang berkaitan dengan ketentuan tersebut.

\subsubsection{Praktek Monopoli Dalam Kaitannya Dengan Pasal 17 Nomor 5 Tahun} 1999

Pasal 17 Undang-Undang Nomor 5 Tahun 1999 hal Reason, teori dalam hal ini mendukung, Pasal tersebut termasuk juga penjabaran unsur praktek monopoli. Monopoli kaitannya dengan Pasal 17 Nomor 5 Tahun 1999 (Reason) adalah memiliki kemampuan teknis, kemampuan merupakan pengetahuan khusus yang mewajibkan melakukan efesiensi dari segi ekonomi, biaya semakin menurun sehingga biaya produksinya lebih rendah, memiliki kemampuan control, sumber produksinya, baik berupa sumber dari manusia maupun sember daya produksi.

Palaku usaha dilarang melakukan penguasaan atas produk atas pemesanan barang dan atau jasa yang menyebabkan kerugian para pihak, pelaku usaha patut didengar dan atau dianggap melakukan penguasaan atas produksi pemesanan barang dan atau jasa. Dari segi penjabarannya dalam pasal 17 (Reason) secara teori dapat dipahami bahwa pelaku usaha masuk dalam kaitannya ketentuan umum, UndangUndang Nomor 5 Tahun 1999 bahwa (setiap orang atau perorangan) selain itu 
pengusaha atas penguasaan pasar yang nyata atas suatu pasar bersangkutan, sehingga dapat menentukan dan atau mengendalikan harga barang dan jasa di pasar tertentu, selaku itu barang sesui Pasal 1 Angka 16 ketentuan umum Undang-Undang Nomor 5 Tahun 1999 bahwa setiap benda baik benda berwujud atau tidak berwujud, benda bergerak maupun benda tidak bergerak, yang dapat diperdagangkan atau dimanfaatkan oleh ketentuan oleh pelaku usaha. Pasal 1 Ayat (17) dalam kaitannya Undang-Undang Nomor 5 Tahun 1999 adalah menyangkut langsung yang berbentuk pekerjaan atau yang dapat diperdagangkan pada masyarakat untuk dimanfaatkan oleh konsumen palaku usaha.

Selanjutnya, beberapa Pasal antara lain 19 Undang-Undang Nomor 5 Tahun 1999 adalah bentuk yaitu bentuk pasal 19 kaitannya dengan pasal 17 bahwa penguasaan Pasal tersebut tentang kerugian para pihak, Pasal lainnya Pasal 20 karena adanya kaitan dengan jual-beli, harga dan nilai serta barang yang didapat merugikan konsumen, Pasal 25 yang menentukan posisi dominan yang memiliki pelaku usaha.

Komisi Pengawas Persaingan Usaha dalam pembuktian adanya dugaan pelanggaran Pasal 17 menggunakan pendekatan Rule Of Reason yang dapat dibagi kedalam beberapa tahap yang meliputi:

1. Pemahaman tentang suatu pasar;

2. Pembuktian posisi dominan;

3. Memiliki posisi dominan; dan

4. Pelaku pembuktian. 
Jurnal Cahaya Keadilan

P-ISSN: 2339-1693

Vol. 9 No. 2 Oktober 2021

E-ISSN: 2580-2461

Program Studi Ilmu Hukum Universitas Putera Batam

Keterangan:

Pendekatan Role Of Reason diatas membuktikan bahwa KPPU memahami kondisi suatu pasar tertentu, atau pasar merupakan menjual bahan pokok atau pasar primer, memahami siapa yang lebih dominan dalam menentukan harga dan atau produk yang harus dijual, memahami pembuktian jika benar terjadi pelanggaran Pasal 17 UNdang-Undang Nomor 5 Tahun 1999 kaitannya dengan Role Of Reason.

\subsection{Pembahasan}

\subsubsection{Komisi Pengawas Persaingan Usaha Menurut Undang-Undang Nomor 5}

Tahun 1999 Tentang Larangan Praktek Monopoli Dan Persaingan Usaha Tidak Sehat

\section{A. Siapakah KPPU}

KPPU adalah Lembaga Indepeneden yang mengawasi pelaksanaan UndangUndang Nomor 5 Tahun 1999, komisi ini bertanggung jawab kepada Presiden, di angkat dan diberhentikan oleh Presiden atas persetujuan DPR, KPPU terdiri dari seorang Ketua merangkap anggota dan sekurang-kurang 7 (tujuh) orang angora. KPPU memiliki 5 (lima) kantor wilayah (kanwil) dengan wilayah kerja sebagai berikut:

1. Kanwil I (medan) Sumatera Utara, Sumatera Barat, Aceh, Riau, dan Kepuluan Riau; 
2. Kanwil II (Lampung) Sumatera Selatan, Jambi, Lampung, Bengkulu, dan Bangka Belitung;

3. Kanwil III (Bandung) Banten, Jawa Barat, dan DKI Jakarta;

4. Kanwil IV (Surabaya) Jawa Timur, Jawa Tengah, Daerah Istimewa Yogyakarta, Bali, Nunsa Tenggara Barat, dan Nusa Tenggara Timur;

5. Kanwil V (Balik Papan) Gorontalo, Sulawesi Tenggara, Sulawesi Selatan, Sulawesi Tengah, Sulawesi Utara, Sulawesi Barat, Maluku, Maluku Utara, Papua, dan Papua Barat.

\section{B. Tugas Utama KPPU}

KPPU memiliki kewenangan untuk memberikan saran dan pertimbangan atas kebijakan pemerintah yang mengarah pada persaingan usaha tidak sehat. Melalui Undang-Undang Nomor 20 Tahun 2008 jo PP Nomor 17 Tahun 2013, KPPU memiliki kewenangan untuk mengawasi dan menegakkan hukum atas pelaksanaan kemitraan antara pelaku usaha dengan UMKM. Penegakan hukum, Advokasi Kebijakan pengendalian marger dan pengawasan kemitraan melambangkan KPPU memiliki kewenangan menyelidiki, memeriksa, dan memutuskan dengan pelanggaran usaha tidak sehat oleh pelaku bisnis, melalui perkuatan PP Nomor 57 Tahun 2010, KPPU memiliki kewenangan mengevaluasi marger yang dimodifikasi dan dikonsultasikan. 
Program Studi Ilmu Hukum Universitas Putera Batam

\section{Tugas dan Kewenangan}

Tugas KPPU berdasarkan Pasal 35 Undang-Undang Nomor 5 Tahun 1999 antara lain melakukan penilaian atas masyrakat, perbuatan pelaku usaha dan penyalahgunaan posisi dominan, mengambil Tindakan sesuai wewenang, memberikan saran kebijakan persaingan kepada pemerintah, Menyusun pedoman dan publikasi terkait Undang-Udang dan memberikan laporan berkala kepada Presiden dan DPR. Pasal 36 Undang-Undang Nomor 5 Tahun 1999 mengenai laporan dari masyarakat, menyiapkan hasil penyelidikan dan pemeriksaan, meminta bantuan penyidik untuk menghadirkan setiap orang yang tidak memenuhi panggilan, mendapatkan, meneliti surat, dokumen dan atau alat bukti lainnya, memberikan putusan Komisi kepada terlapor, dan sebagainya.

\section{Kantor Wilayah II}

Tugas : mengkoordinasikan penyelenggaraan dukungan Administratif, kantor wilayah dipimpin kepala kantor wilayah dengan jabatan setingkat direktur, dalam pelaksanaan tugasnya, kepala kantor wilayah bertanggung jawab kepada komisioner dan secara administratif bertanggung jawab kepada sekretaris jenderal. Dari 4 (empat) hal di atas tujuannya dalah menjaga kepentingan umum dan meningkatkan efisiensi nasional sebagai upaya mensejahterakan masyarakat, menjamin kesempatan berusaha yang sama bagi pelaku usaha besar, menengah dan kecil, mencegah praktek monopoli dan atau persaingan usaha tidak sehat serta efektifitas dan efesiensi kegiatan usaha. 
Program Studi Ilmu Hukum Universitas Putera Batam

\subsubsection{Pendekatan Terhadap Pelarangan Undang-Undag Nomor 5 Tahun 1999 Kaitannya Dengan Pasal 17 Rule Of Reason}

Pendekatan pelarangan kaitannya Rule Of Reason, bisa dilakukan pendekatan Per Sell Illegal, yaitu setiap perjanjian atau kegiatan usaha tertentu dianggap illegal, sehingga tidak diperlukan pembuktian lebih lanjut atas dampak persaingan yang tidak sehat yang dapat ditimbulkan dari perjanjian atau kegiatan tersebut, contohnya Pasal 5 tentang penetapan harga dan Pasal 15 tentang perjanjian tertutup.

Khusus Pasal 17 Undang-Undang Nomor 5 Tahun 1999, Rule Of Reason adalah suatu pendekatan guna mengevaluasi akibat dari perjanjian atau kegiatan usaha tersebut sehingga dapat ditentukan apakah perjanjian atau kegiatan usaha tersebut bersifat menghambat atau mendukung. Contoh Pasal 17 tentang Monopoli. Contoh lain dapat dilihat pada PAsal 11 samapai Pasal 16, kegiatan yang dilarang Pasal 17 samapai Pasal 24, Posisi dominan Pasal 25 sampai Pasal 29, dan seterusnya.

Jenis pelanggaran Undang-Undang Nomor 5 Tahun 1999, perjanjian dengan pihak lain oerjanjian tertutup Oligopsoni, Trust, Integritas vertical, Kartel, Oligopoli dan penetapan harga, posisi tersebut merupakan perjanjian yang dilarang karena menyalahgunakan posisi dominan ( posisi dominan kepemilikan saling jabatan rangkap Marger) kegiatan yang dilarang yaitu Monopoli penguasaan Pasar, persengkokolan tender.

\section{Perjanjian yang dilarang:}


Jurnal Cahaya Keadilan

P-ISSN: 2339-1693

Vol. 9 No. 2 Oktober 2021
E-ISSN: 2580-2461

Program Studi Ilmu Hukum Universitas Putera Batam

1. Oligopoli adalah suatu bentuk pasar persaingan tidak sempurnah, karena hanya terdapat beberapa produsen atau penjual dengan banyak pembeli di pasar hal disebabkan adanya kelebihan dan kekurangan pasar oligopoli adalah memberi kebebasan memiliki bagi pembeli dan lebih memperhatikan kepuasan konsumen karena adanya persaingan penjual.

2. Penerapan Harga adalah suatu strategi yang menjadi kendala perusahaan sebagai bentuk regulasi . dengan persaingan pasar secara global yang semakin sengit (Pasal 5 samapai Pasal 8)

3. Pemboikotan-Pemboikotan adalah suatu proses, cara, perbuatan pemboikot atau bersengkokol untuk kegaiatn dan ini dilarang oleh Undang-Undang (Pasal 20).

4. Oligopsony (Pasal 23) adalah bentuk pasar dimana terdapat dan atau pembeli.

5. Perjanjian Tertutup (Pasal 25) Undang-Undang Nomor 5 Tahun 1999 baru penerima kas berikutnya di akui sebagai kotor barang jual tersebut bisa saja barang yang di larang atau penjaualan gelap.

Undang-Undang menegaskan bahwa didalam Pasal (17 Undang-Undang Nomor 5 Tahun 1999 Ayat (2 C) harus dibuktikan karena sifatnya Rule Of Reason. Misalnya saja Kasus yang Oligopoli dan monopoli proses pembuktian mengenal 2 (dua) macam alat bukti yaitu alat bukti yang dilarang dan alat bukti yang di larang. 
Program Studi Ilmu Hukum Universitas Putera Batam

\section{PENUTUP}

\subsection{Simpulan}

Berdasarkan pembahasan diatas dapat dirumuskan dan diperbaiki secara integral bahwa pendekatan yang dapat digunakan KPPU adalah menyelesaikan sengketa kaitannya Pasal 17 Undang-Udang Nomor 5 Tahun 1999 adalah pengaliran penggunaan alat bukti langsung dalam proses pembuktian. Rule Of Reason dalam menyelesaikan harus berdasarkan Pasal 11 Undang-Undang Nomor 5 Tahun 1999. Sesuai dengan implikasi dari penerapan pendekatan Rule Of Reason dalam harga persaingan usaha di Indonesia. Intinya, pertama adalah larangan mengadakan bentuk perjanjian kartel (misalnya) serta yang dicantumkan dalam Pasal 11 Undang-Undang Nomor 5 Tahun 1999.

\subsection{Saran}

Sebaiknya Peraturan komisi pengawasan persaingan usaha Nomor 4 Tahun 2010 tentang Panduan Pelaksanaan Pasal 11 Undang-Undang Nomor 5 Tahun 1999 harya alas an dari pelaku usaha saja yang tidak di gunakan oleh Undang-Undang dapat ditindak oleh KPPU berdasarkan perintah Undang-Undang persaingan usaha di peraturan pemerintah Nomor 4 Tahun 2010. 
Jurnal Cahaya Keadilan

P-ISSN: 2339-1693

Vol. 9 No. 2 Oktober 2021

Program Studi Ilmu Hukum Universitas Putera Batam

\section{DAFTAR PUSTAKA}

Ali, Zainuddin, 2016, Metode Penelitian Hukum, Sinar Grafika, Jakarta.

Hermansyah. 2009. Pokok-Pokok Hukum Persaingan Usaha Di Indonesia, Kencana.

Jakarta.

Meylina, Devi ,2003 Hukum Persaingan Usaha, Setara Press, Malang

S, Maria, F.I, 2017, Ilmu Perundang-Undangan, Kanisius, Jakarta

Suyud Margono, 2016 Penyelesaian Sengketa Bisnis, Ghalia Indonesia, Jakarta. 